\title{
Teaching thermodynamics in Engineering based on competences
}

\section{Enseñanza de la termodinámica en Ingeniería con base en competencias}

\author{
RANGEL-ROMERO, Carlos $\dagger^{*}$, ROJAS-GARNICA, Juan Carlos, FLORES-MARTÍNEZ, Guillermo \\ and MUÑOZ-MATA, José Lorenzo
}

Universidad Tecnológica de Puebla

ID $1^{\text {st }}$ Author: Carlos, Rangel-Romero / ORC ID: 0000-0003-4879-4228, CVU CONACYT ID: 894477

ID $1^{\text {st }}$ Coauthor: Juan Carlos, Rojas-Garnica / ORC ID: 0000-0002-2261-587X, CVU CONACYT ID: 66417

ID $2^{\text {nd }}$ Coauthor: Guillermo, Flores-Martínez / ORC ID: 0000-0002-2243-2379, CVU CONACYT ID: 69853

ID $3^{\text {rd }}$ Coauthor: José Lorenzo, Muñoz-Mata / ORC ID: 0000-0001-7813-5579, CVU CONACYT ID: 177117

DOI: $10.35429 / E J S .2019 .10 .6 .22 .26$

Received April 08, 2019; Accepted June 30, 2019

\begin{abstract}
This paper shows an analysis of the activities carried out in the classroom on topics which involve thermodynamics. This proposal contemplates methodological aspects and competences of the subject on basic topics that involve the understanding of the phenomena involving the first and second laws of thermodynamics. The proposal aims for the student to develop a cognitive process which can be used as a tool to help improve their learning. This process is characterized by a feedback between the implementation of the changes concerning the teachinglearning process and the evaluation process of the achieved learning. The analysis of the evaluation is based on the phenomena that involve fundamental concepts such as energy, work and heat, as well as the need to develop assessment instruments according to the competence that the student needs to develop. The results show a significant progress, in terms of the level of learning achieved, by making an annual comparison of school performance based on a competency scheme.
\end{abstract}

Teaching, Thermodynamics, Competency

\begin{abstract}
Resumen
El presente trabajo muestra un análisis de las actividades realizadas en el aula sobre temas que involucran a la termodinámica. Esta propuesta contempla aspectos metodológicos y de competencias de la materia sobre temas básicos que involucran la comprensión de los fenómenos que involucran a la primera y segunda ley de la termodinámica. La propuesta pretende que el alumno desarrolle un proceso cognitivo que pueda ser usado como herramienta que ayude al proceso de mejora en cuanto a su aprendizaje. Este proceso se caracteriza por una retroalimentación entre la implementación de los cambios referentes al proceso de enseñanza aprendizaje y el proceso de evaluación del aprendizaje logrado. El análisis de la evaluación se realiza con base a los fenómenos que involucran a los conceptos fundamentales como energía, trabajo y calor, así como en la necesidad de elaborar los instrumentos de evaluación de acuerdo a la competencia que el alumno necesita desarrollar. Los resultados encontrados muestran un avance significativo, en cuanto al nivel de aprendizaje logrado, al realizar una comparativa anual de aprovechamiento escolar basado en un esquema de competencias.
\end{abstract}

\section{Enseñanza, Termodinámica, Competencias}

Citation: RANGEL-ROMERO, Carlos, ROJAS-GARNICA, Juan Carlos, FLORES-MARTÍNEZ, Guillermo and MUÑOZMATA, José Lorenzo. Teaching thermodynamics in Engineering based on competences. Journal-Spain. 2019. 6-10: 22-26

\footnotetext{
* Correspondence to Author (carlos.rangel@utpuebla.edu.mx)

$\dagger$ Researcher contributing as first author.
} 


\section{Introduction}

In the development of the teaching practice, lack of analysis and reasoning of significant knowledge is manifested daily in students; memorization has been strengthen, largely replacing reasoning, fractioning learning on small islands, without relating the contents in a scientific way.

This pedagogical breakdown, with the development of skills and competences, leads the teacher and the student to an uncertain pedagogical process not in accordance to the needs of the labor market. Therefore, the model focused on competencies considers important aspects towards the student, such as: focusing on the student the responsibility of building and structuring their knowledge, leaving teachers the role of facilitators, guides and motivators of student learning, likewise, that of achieving coherence between the curricula and the training processes which involve the teaching-learning process, and that of obtaining a balance between the theoretical teaching activities with the objective of reaching the required skills and competencies of the student in their professional training and consequent labor insertion. It is also essential that students develop reading abilities that allow them to understand knowledge in all its magnitude and also incorporate a sense of social responsibility.

In this pedagogical context, and given the challenges of current education, it is believed that competences can be grouped in 3 domains: training and personal development, communication, and development of scientific thinking.

Selected knowledge, specific skills and values reflected in professional attitudes and behaviors concur during the development of the competences. For this, we carried out a pedagogical strategy which begins with the learning process in the field of thermodynamics; this was complemented with other techniques to ensure that students acquire the competence that the subject requires in order to define the areas in which the professional develops, thus delineating the skills from the domains of the subject.

\section{Development}

In the development of the aforementioned competences, it is necessary to recognize that the strategy, method, techniques and assistance must be focused on student learning, so inherently the teacher must surround the learning process with the necessary scientific information with an appropriate pedagogical strategy.

That is why the teaching-learning process is considered as a set of dynamic interactions which involve the teacher and students, where the former has as main purpose integral formation, including the knowledge of the subject, the skills for the teaching process and attitudes, all of them aimed at the student's own cognitive process, as well as an organized management which includes the knowledge acquired. To develop a competence, it is necessary for the teacher to guide by creating situations focused on reality within the work context, using strategies that give the best results to exchange, share, confront and debate ideas, making students form new structures. It is important to mention that the strategy to be used should consider reflection as an important part to deal with practical problems and thus face the discrepancy between reality and what was expected. When teaching with reflexive activity, not only do students get used to understanding the concepts, but they contribute new meanings and structure their ideas, analyzing the processes and expressing their thoughts in a better way.

For teaching the subject of thermodynamics, we chose to apply the cooperative learning strategy. It is an organized and structured method that includes team building activities, the preparation and formal presentation of the information acquired, practice in solving problems and the evaluation of each student. It is important to mention that the progress achieved by the students is very significant, since it encourages students to be self-taught, to be more sociable and that they try to generate their own learning in terms of the subjects they do not understand. Cooperative learning promotes collaborative work because it allows for better relationships between students, those who learn better, feel more motivated and, in addition, make their social skills much more effective by being part of a cooperative group. 
It is relevant to point out that each of the teams strives to obtain recognition for the work done by each member, which translates into a noticeable improvement in their school performance.

Likewise, individual responsibility develops from the moment in which each of the members knows that they will have to be evaluated in relation to the proficiency of the subject presented. The team members prepare, practice together and explain to each other the topics that are not understood, since the grade of the team is based on the progress demonstrated by the students, a situation that forces them to pay more attention when the topic is explained by the teacher.

\section{Result analysis}

It is important to mention that not all work group is a cooperative learning group, since there are still traditional work groups in which the most skilled students assume leadership and benefit from the team experience; also there are students who only perform functions such as photocopying, drawing or capturing texts. In these teams, cooperative learning is forgotten and becomes very personal. This inappropriate distribution of activities usually causes problems such as struggle for power, division, distrust, selfishness and segregation of the group.

This type of situations is often reflected in the development of professional activities and is the reason why many people still do not believe in teamwork. That is why it is important to be aware of how much this happens, since it implies individualistic situations and there is no relationship between the objectives pursued by each student, because their goals are independent of each other. For cooperative learning, the action of cooperating represents the fact of working together to achieve shared goals and, for this, teamwork has very positive effects not only on academic performance, as evidenced by the fact that interpersonals relationships develop very favorably, as they increase respect and solidarity, as well as feelings of obligation and help.

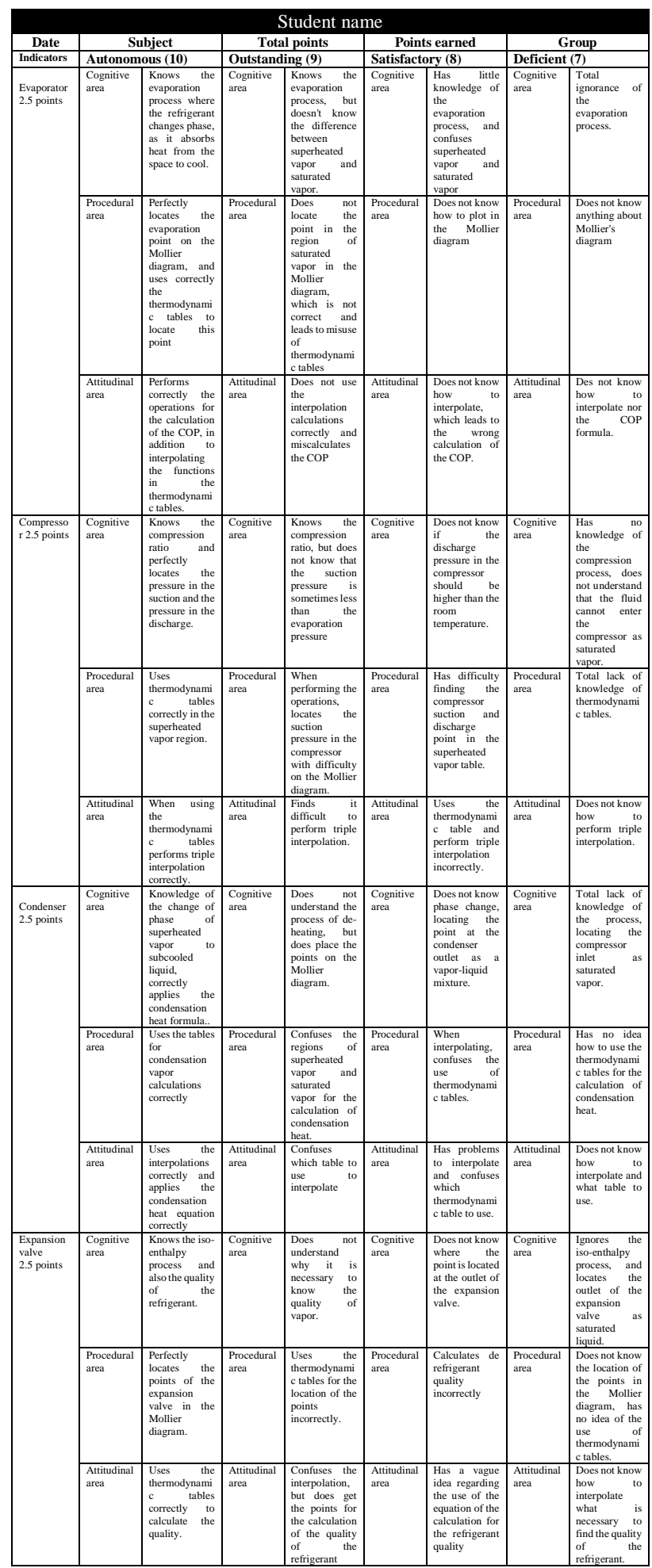

Table 1 Rubric used for the evaluation of a refrigeration system

Source: Prepared by the authors.

The results achieved with the implementation of the competency approach can be discussed from different perspectives, the most relevant being the following: In relation to the training modality, it can be indicated that by implementing the competency method it is possible to clearly define which strategies, methodologies and activities should be used by the teacher so that students can reach the competences and abilities which obviously facilitate the evaluation process.

RANGEL-ROMERO, Carlos, ROJAS-GARNICA, Juan Carlos, FLORES-MARTÍNEZ, Guillermo and MUÑOZ-MATA, José Lorenzo. Teaching thermodynamics in Engineering based on competences. Journal-Spain. 2019 
Regarding the students, there was an increase in their direct participation during the learning process. Approximately 30\% of the teaching hours correspond to activities carried out by the students themselves. During their development, they expressed approval of the activities designed, since they could better visualize what they are capable of doing. The evaluation system was more varied and adapted to the new conditions, in which the relevant point is to check the achievement of competencies. A diverse range of assessment instruments were available, such as essay tests, laboratory work, reports, collaborative work, etc., which allow for a better decision regarding the passing or faling of a particular student in each unit, depending on whether or not they have developed the defined competencies. Table 1 shows a rubric used to evaluate thermodynamic concepts of a refrigeration system.

\section{Acknowledgments}

We appreciate the support provided for the preparation of this work to the Technological University of Puebla.

\section{Conclusions}

The student has to know the professional and labor field in order to develop the skills and competencies essential in their professional development.

The development of competences is strictly related to the pedagogical strategy that focuses on the development of the student's scientific thinking, leaving behind the reduced vision of memorizing isolated and meaningless concepts.

The concrete expression of the development of the process-learning has to do with insertion success in the labor field. The dialogue between those who integrate and act in the learning process will be effective as long as it addresses and links capacity development, discipline, values, and cognitive processes which form and forge professionals capable of analyzing the circumstances and transform them into cognitive initiatives that lead them to professional success. The teacher as facilitator and generator of learning must master the scientific field of their area and propose the most appropriate pedagogical strategy for the student to develop skills and competencies.
Learning, assets and knowledge, when they are the product of joint work, collective and individual analysis, have more possibilities to build paradigms and projects that raise the quality of learning based on concrete-collective reality.

\section{Future work}

In a future work it is essential to systematically record the evidence which allows us to analyze and evaluate the progress attained.

\section{References}

Alarcón, R. (2014). Conferencia Inaugural Universidad 2014, 9no Congreso Internacional de Educación Superior. La Habana: MES.

Azzurro A., Girón P., y Cura R.O. (2014). "Articulación entre docencia e investigación de la enseñanza en entorno industrial". En VIII Congreso Iberoamericano de Docencia Universitaria y Educación Superior. Rosario, Universidad Nacional de Rosario. ISBN 978987-3638-02-2.

Del Rey A., Sánchez J. (2011). Crítica de la educación por competencias. Universitas. Revista de Ciencias Sociales y Humanas (15). Pp. 233-246.

Estrada, John. (2012). La formación por competencias y el mundo del trabajo: de la calificación a la empleabilidad. Revista Salud pública, (1). Pp.98-111.

Fernández, Eduardo. (2009). El discurso de la formación basada en competencias profesionales. Un análisis crítico de la formación inicial de 'profesionales en la Educación Superior. REIFOP, (1), Pp. 151-160.

Filmus, D. (1994). El papel de la Educación frente a los desafíos de las transformación científico-tecnológicas. Publicado con autorización de los editores. Presentado Volumen II, Módulo V del Curso de Formación de Administradores de la Educación, publicado en Buenos Aires por el Ministerio de Cultura y Educación de la República Argentina, la Facultad Latinoamericana de Ciencias Sociales (FLACSO-Buenos Aires) y la Organización de Estados Iberoamericanos para la Educación, la Ciencia y la Cultura (OEI), del libro "Para qué sirve la escuela". Tesis. Grupo editorial Norma. Buenos Aires. Retrieved on February 28, 2011.

RANGEL-ROMERO, Carlos, ROJAS-GARNICA, Juan Carlos, FLORES-MARTÍNEZ, Guillermo and MUÑOZ-MATA, José Lorenzo. Teaching thermodynamics in Engineering based on competences. Journal-Spain. 2019 
García J. (2011). Modelo educativo basado en competencias: Importancia y necesidad. Vol.11, No.3. Pp.1-24.

Ibáñez, C. (2007). Diseño curricular basado en competencias profesionales: una propuesta desde la psicología interconductual. Revista de Educación y Desarrollo, Número XIX (6). Retrieved on February 27, 2011. 